Studia nad Autorytaryzmem i Totalitaryzmem 43, nr 4 Wrocław 2021

https://doi.org/10.19195/2300-7249.43.4.30

\author{
ŁUKASZ GOŹDZIASZEK \\ ORCID: 0000-0003-3843-5037 \\ Uniwersytet Wrocławski \\ lukasz.gozdziaszek@uwr.edu.pl
}

\title{
Obowiązek rejestracji prasy a postęp technologiczny
}

Slowa kluczowe: prasa, media, rejestracja, internet, prawo.

\section{THE OBLIGATION TO REGISTER THE PRESS AND TECHNOLOGICAL PROGRESS}

\begin{abstract}
The aim of the article is to show the evolution of the requirements related to publishing the press and to define the directions of new legal changes. The current regulations are inadequate to the contemporary realities of the media market and communication possibilities. The obligation to register the press can be seen as a relaxed follow-up to the authoritarian or totalitarian regimes' requirement to obtain a license to publish a journal or a periodical. Press registration would be a democratic alternative to obtaining a press license only if certain values supported it, including the interests of other persons and entities. Currently, such interests are secured by other regulations. The considerations of the courts and legal science focus on the possible contradiction of the current regulation on the registration of newspapers and magazines with the constitutional ban on licensing the press. However, it should be taken into account to a greater extent that the dissemination of the internet and computer hardware has made it more complicated to register a periodical than to start a simple press activity. Therefore, the obligation to register the press in its present form is unreasonable.
\end{abstract}

Keywords: press, media, registration, internet, law. 


\section{Wprowadzenie}

Celem artykułu jest scharakteryzowanie ewolucji formalnych czynności koniecznych do rozpoczęcia wydawania prasy, a także określenie pożądanych zmian prawnych. Obecny stan prawny jest nieadekwatny do współczesnych realiów rynku medialnego i możliwości komunikacyjnych. Upowszechnienie sieci internetowej spowodowało, że dotychczasowe regulacje prawa prasowego ${ }^{1}$ stały się niejasne ${ }^{2}$. Dotyczy to zwłaszcza kluczowej w tej materii definicji prasy, statuowanej w art. 7 ust. 2 pkt 1 P.p. Choć brak częstych nowelizacji mógłby świadczyć o ostrożności w dokonywaniu zmian, a tym samym o poszanowaniu wartości prawa prasowego, to takiemu ujęciu przeczy jednak okoliczność, że zmiany następowały wskutek orzeczeń Trybunału Konstytucyjnego ${ }^{3}$. Nowelizacje były zatem konieczne, ale zostały dokonane dopiero na skutek działań Trybunału. Na marginesie należy dostrzec, że prawo prasowe przez długi okres zawierało nawet wiele archaicznych regulacji, jak choćby do 23 maja 2011 roku art. 24 P.p. mówił o Komitecie do Spraw Radia i Telewizji „Polskie Radio i Telewizja”, który zakończył funkcjonowanie w 1993 roku.

Kwestia sprzeczności obecnej regulacji dotyczącej rejestracji dzienników i czasopism z konstytucyjnym zakazem koncesjonowania (art. 14 i 54 ust. 2

${ }^{1}$ Ustawa z dnia 26 stycznia 1984 roku - Prawo prasowe (tekst jedn. Dz.U. z 2018 r. poz. 1914, dalej: ,„prawo prasowe” lub „P.p.”).

2 Zob. S.J. Malinowski, Status prawny Internetu w świetle Konstytucji RP i obowiazujacego prawodawstwa polskiego, „Prawo Mediów Elektronicznych” 2020, nr 1, s. 23. Por. J. Barta, R. Markiewicz, Postęp techniczny w mediach, [w:] Prawo mediów, red. J. Barta, R. Markiewicz, A. Matlak, Warszawa 2005. Internet w obecnym kształcie przyczynia się również do zaburzenia klarownego dotąd podziału na dzienniki, czasopisma, radio i telewizję (zob. między innymi K. Klafkowska-Waśniowska, Elektroniczne wersje gazet $i$ czasopism a audiowizualne ustugi medialne w prawie Unii Europejskiej i prawie polskim. Glosa do wyroku TS z dnia 21 października 2015 r., C-347/14, „Europejski Przegląd Sądowy” 2016, nr 8, s. 45-50). W dalszej części publikacji internet będzie postrzegany głównie jako instrument, który doprowadził do przełomu technicznego, a w kontekście działalności prasowej przyczynił się do znacznego obniżenia wymagań technicznych do rozpoczęcia działalności prasowej, w szczególności jeśli nie aspiruje ona do wysokich walorów wizualnych, a skupia się jedynie na przekazie tekstowym. Jednak oprócz tego trzeba zauważyć, że sieć internetową można postrzegać w kontekście ,prawa do internetu” (zob. M. Zieliński, Dostęp do Internetu jako prawo czlowieka? W sprawie potrzeby nowej wolności w Konstytucji Rzeczypospolitej Polskiej, „Przegląd Sejmowy” 2013, nr 4, s. 9-22; K. Stępniak, Prawo do Internetu jako środka zapewniającego partycypację w państwie demokratycznym, „Studia Prawnicze i Administracyjne" 2017, nr 3, s. 65-70).

3 Zob. wyrok Trybunału Konstytucyjnego z dnia 1 grudnia 2010 roku, sygn. K 41/07 (Dz.U. z 2010 r. Nr 235, poz. 1551), wyrok Trybunału Konstytucyjnego z dnia 14 grudnia 2011 roku, sygn. SK 42/09 (Dz.U. z 2011 r. Nr 282, poz. 1660), wyrok Trybunału Konstytucyjnego z dnia 18 lipca 2011 roku, sygn. K 25/09 (Dz.U. z 2011 r. Nr 156, poz. 934), wyrok Trybunału Konstytucyjnego z dnia 22 lutego 2005 roku, sygn. K 10/04 (Dz.U. z 2005 r. Nr 39, poz. 377) i wyrok Trybunału Konstytucyjnego z dnia 5 maja 2004 roku, sygn. P 2/03 (Dz.U. z 2004 r. Nr 111, poz. 1181). 
Konstytucji $\mathrm{RP}^{4}$ ) była przedmiotem niemałego zainteresowania orzecznictwa ${ }^{5}$ i doktryny ${ }^{6}$. Za fundamentalne uchodzić może twierdzenie wyrażone przez Trybunał Konstytucyjny w wyroku z 2007 roku $^{7}$, że system rejestracyjny jest bliski „czystemu” systemowi zgłoszeniowemu i przeciwstawny wobec systemu koncesyjnego (prewencyjnego). Zdaniem Trybunału Konstytucyjnego, przyjęty w prawie prasowym ,tryb rejestracyjny jest odmianą szeroko pojętego systemu zgłoszeniowego" i ,z całą pewnością nie mieści się w modelu koncesjonowania prasy oraz nie ma nic wspólnego z cenzurą prewencyjną, które to rozwiązania prawne są zakazane przez art. 54 ust. 2 Konstytucji RP”. Takie ujęcie jedynie pozornie rozwiązuje kontrowersje i w gruncie rzeczy przesłania problem. Nawet gdyby przyjąć, że obecny system nie zagraża wolności prasy, to może on sam w sobie stanowić narzędzie do ograniczania wolności słowa (art. 54 ust. 1 Konstytucji RP). Wynika to z okoliczności, że zakres przedmiotu rejestracji jest, zwłaszcza na gruncie mediów internetowych, na tyle nieklarowny (można również uznać, że jest zbyt szeroki), iż pozwala wyciągać negatywne konsekwencje za brak rejestracji działalności, której kwalifikacja związana z dziennikarstwem jest wątpliwa.

${ }^{4}$ Odnośnie do przeglądu najnowszych stanowisk dotyczących przełamywania absolutyzacji wolności prasy i sytuowania prasy w systemie społecznym zob. J. Taczkowska-Olszewska, Racjonalizacja wolności prasy —od modelu absolutnego do warunkowego. Europejski i krajowy kontekst wyktadni prawa, „Przegląd Sejmowy” 2018, nr 1. W kontekście koncesjonowania zob. również rozważania na temat cenzury prewencyjnej: E. Nowińska, Wolność wyrażania poglądów a cenzura prewencyjna. Próba interpretacji Konstytucji, [w:] eadem, Wolność wypowiedzi prasowej, Warszawa 2007; Ł. Machaj, Glosa do wyroku TK z dnia 9 listopada 2010 r., K 13/07, „Przegląd Sejmowy” 2011, nr 3; W. Sokolewicz, Wolność prasy i jej konstytucyjne ograniczenia, „Państwo i Prawo” 2008, nr 6, s. 24.

5 Zob. w szczególności wyrok Trybunału Konstytucyjnego z dnia 20 lutego 2007 roku, sygn. P 1/06 („Orzecznictwo Trybunału Konstytucyjnego. Zbiór Urzędowy” 2007, z. 2A, poz. 11) i wyrok Trybunału Konstytucyjnego z dnia 14 grudnia 2011 roku sygn. SK 42/09 („Orzecznictwo Trybunału Konstytucyjnego. Zbiór Urzędowy" 2011, z. 10A, poz. 118).

${ }^{6}$ K. Paczoska, Komentarz do art. 20, [w:] Prawo prasowe. Komentarz, red. B. Kosmus, G. Kuczyński, Warszawa 2018, Legalis, nb 4; J. Sadomski, Komentarz do art. 54, [w:] Konstytucja RP. Komentarz, red. M. Safjan, L. Bosek, Warszawa 2016, Legalis, nb 34; E. Ferenc-Szydełko, Komentarz do art. 20, [w:] Prawo prasowe. Komentarz, Warszawa 2013; oraz M. Brzozowska-Pasieka, Komentarz do art. 20, [w:] Prawo prasowe. Komentarz praktyczny, red. M. Olszyński, J. Pasieka, M. Brzozowska-Pasieka, Warszawa 2013. B. Banaszak zwrócił uwagę, że istniejący system rejestracyjny spotyka się z krytyką przedstawicieli nauki prawa; idem, Komentarz do art. 54, [w:] idem, Konstytucja Rzeczypospolitej Polskiej. Komentarz, Warszawa 2012, Legalis, nb 12. Wskazać należy w tym kontekście przede wszystkim: W. Sokolewicz, op. cit., s. 23; E. Czarny-Drożdżejko, Obowiązkowa rejestracja dzienników i czasopism na gruncie ustawy - Prawo prasowe, „Przegląd Sądowy” 2013, nr 10, s. 56; G. Tylec, Obowiąek rejestracji tytułów prasowych, [w:] idem, Ochrona tytulu utworu w prawie polskim, Warszawa 2006.

7 Wyrok Trybunału Konstytucyjnego z dnia 20 lutego 2007 roku, sygn. P 1/06 („Orzecznictwo Trybunału Konstytucyjnego. Zbiór Urzędowy” 2007, z. 2A, poz. 11). 
Warto przy tym podkreślić, że Trybunał Konstytucyjny wprost zasygnalizował ustawodawcy w wyroku z 2011 roku $^{8}$, że obecne prawo prasowe ,nie jest aktem prawnym dostosowanym do współczesnych form działalności prasy wynikających z postępu technologicznego, jaki dokonał się w okresie wielu lat od wejścia w życie prawa prasowego”. Wskazał także, iż „w pracy nad nową ustawą o prawie prasowym potrzebna będzie również konfrontacja proponowanych rozwiązań ze współczesnymi standardami państwa demokratycznego". Dotychczas jedyną istotną odpowiedzią ustawodawcy na istniejące wątpliwości była zmiana $\mathrm{w}$ art. 45 P.p. i ustanowienie art. 54c P.p. (nowelizacja ${ }^{9} \mathrm{w}$ tym przedmiocie weszła w życie 19 lipca 2013 roku). Nie jest to jednak kompleksowa odpowiedź.

\section{Rejestracja w miejsce zezwolenia}

Ewolucja legislacji w przedmiotowym zakresie ${ }^{10}$ ukazuje, że pomimo radykalnej zmiany uwarunkowań ustrojowych, rewolucji internetowej i, ogólnie rzecz ujmując, roli prasy w realizacji swobody wypowiedzi nowelizacje w ostatnich dekadach na poziomie ustawowym nie były równie przełomowe. W myśl art. 17 dekretu z 1938 roku (w wersji pierwotnej) ${ }^{11}$ kto zamierzał wydawać czasopismo, powinien „zgłosić o tym na piśmie” właściwej powiatowej władzy administracji ogólnej i podać:

- tytuł wydawnictwa, jego zakres, termin i miejsce wydawania;

- adres redakcji i administracji;

— imiona, nazwiska i adresy redaktorów;

- zakład, w którym czasopismo będzie odbijane;

— imiona, nazwiska i adresy wydawców, właścicieli, użytkowników i dzierżawców czasopisma.

Władza administracyjna miała wydawać natychmiast bezpłatne potwierdzenie zgłoszenia. Samo wydanie ,potwierdzenia zgłoszenia”, wbrew pozorom, nie kończyło sprawy. W gruncie rzeczy dalsze czynności były w istotnym stopniu podobne do obecnego trybu rejestrowego, pomimo że przedwojenne uregulowanie posługuje się pojęciem zgłoszenia. Nadmienić przy tym należy, że dawny stan prawny odnosił się do „czasopism”, a nie, jak obecnie, do „dzienników

${ }^{8}$ Wyrok Trybunału Konstytucyjnego z dnia 14 grudnia 2011 roku, sygn. SK 42/09, „Orzecznictwo Trybunału Konstytucyjnego. Zbiór Urzędowy” 2011, z. 10A, poz. 118.

9 Ustawa z dnia 10 maja 2013 roku o zmianie ustawy - Prawo prasowe (Dz.U. z 2013 r. poz. 771).

10 Szerzej zob. J. Sieńczyło-Chlabicz, Z. Zawadzka, M. Nowikowska, Historia prawa prasowego w Polsce. Podstawowe pojęcia z zakresu prawa mediów, [w:] Prawo mediów, red. J. Sieńczyło-Chlabicz, Warszawa 2015, s. 15-22; R. Habielski, Ewolucja prawa prasowego w Drugiej Rzeczypospolitej. Zakres i recepcja, „Studia Medioznawcze” 2013, nr 4, s. 79-93.

11 Dekret Prezydenta Rzeczypospolitej z dnia 21 listopada 1938 roku - Prawo prasowe (Dz.U. z 1938 r. Nr 89, poz. 608). Utracił moc na podstawie art. 60 P.p. 
i czasopism", co jednak jest jedynie konsekwencją tego, że w ówczesnym stanie prawnym nie wyodrębniono instytucji „dziennika”, a jedynie — „czasopisma”.

Co najistotniejsze, zgodnie $\mathrm{z}$ art. 18 dekretu z 1938 roku wydawanie czasopisma wolno było rozpocząć, jeżeli władza administracyjna nie udzieliła odpowiedzi w ciągu czternastu dni od zgłoszenia albo jeżeli przed upływem tego terminu zawiadomiła, że zgłoszenie nie wywoływało zastrzeżeń. Władza administracyjna mogła również przed upływem terminu czternastodniowego wstrzymać rozpoczęcie wydawania czasopisma:

— jeżeli zgłoszenie nie zawierało danych, określonych w art. 17 dekretu z 1938 roku;

— jeżeli redaktor nie odpowiadał warunkom, określonym w art. 16 dekretu z 1938 roku;

— jeżeli tytuł czasopisma był taki sam, jak już wydawanego lub zgłoszonego w Polsce;

— jeżeli ze zgłoszenia wynikało, że nowe czasopismo ma się nieznacznie różnić od czasopisma zawieszonego.

Zgłoszenie traciło moc, jeżeli w ciągu sześciu miesięcy od jego dokonania czasopismo nie ukazało się albo jeżeli przerwa w wydawnictwie trwała ponad rok.

Istotne zmiany dokonały się mocą dekretu z 1946 roku$^{12}$. Przepis art. 1 pkt 3 tego dekretu stanowił, że do zadań Głównego Urzędu Kontroli Prasy, Publikacji i Widowisk należało udzielanie zezwoleń na wydawanie czasopism. Pod rządami ówcześnie obowiązującego prawa prasowego, ale w jego pierwotnym brzmieniu, kwestia będąca przedmiotem analizy w niniejszej publikacji była uregulowana w art. 19 i 20 P.p. Pierwsza z tych regulacji dotyczyła zezwolenia na prowadzenie prasowej działalności wydawniczej lub nakładczej, a druga — wydawania dziennika lub czasopisma. Przepis art. 19 P.p. został skreślony z dniem 6 czerwca 1989 roku ${ }^{13}$, kiedy też weszła $\mathrm{w}$ życie nowelizacja art. 20 P.p. W tym miejscu należy zauważyć, że znamiennym byłoby, gdyby art. 20 P.p. został skreślony analogicznie do art. 19 P.p. i gdyby ewentualnie został ustanowiony nowy artykuł dotyczący rejestracji. Byłoby to wyrazem przyjęcia, że obecne rozwiązanie z art. 20 P.p. to całkowicie inny system niż przewidziany w dawnym brzmieniu art. 20 P.p., a nie tylko jego modyfikacja.

Dawny art. 19 ust. 1 i 2 P.p. stanowił mianowicie, że prowadzenie prasowej działalności wydawniczej lub nakładczej wymaga zezwolenia, a w celu jego

12 Dekret z dnia 5 lipca 1946 roku o utworzeniu Głównego Urzędu Kontroli Prasy, Publikacji i Widowisk (Dz.U. z 1946 r. Nr 34, poz. 210). Dekret ten utracił moc na podstawie ustawy z dnia 31 lipca 1981 roku o kontroli publikacji i widowisk (Dz.U. z 1981 r. Nr 20, poz. 99). Z kolei ustawa ta została uchylona mocą ustawy z dnia 11 kwietnia 1990 roku o uchyleniu ustawy o kontroli publikacji i widowisk, zniesieniu organów tej kontroli oraz o zmianie ustawy — Prawo prasowe (Dz.U. z 1990 r. Nr 29, poz. 173).

13 Ustawa z dnia 30 maja 1989 roku o zmianie ustawy - Prawo prasowe (Dz.U. z 1989 r. Nr 34, poz. 187). 
uzyskania organ założycielski wydawnictwa lub inny właściwy organ, a także osoba fizyczna składały pisemny wniosek do Głównego Urzędu Kontroli Publikacji i Widowisk. Wniosek powinien zawierać nazwę i adres wydawcy, określać charakter i zakres zamierzonej działalności wydawniczej, jak również ich zgodność ze statutem wydawcy, jeżeli jest osobą prawną, a także wskazywać zamierzone sposoby zaopatrzenia w papier i możliwości wytwarzania za pomocą druku lub innej techniki. Wniosek powinien zawierać też niezbędne dane osobowe zarządzających tworzonym wydawnictwem, $\mathrm{z}$ określeniem zakresu odpowiedzialności każdej z tych osób (art. 19 ust. 3 P.p. w pierwotnym brzmieniu). Ponadto osoba fizyczna ubiegająca się o zezwolenie na prasową działalność wydawniczą była obowiązana przedstawić opinię właściwego wojewody, uzasadniającą potrzebę uruchomienia prywatnego przedsiębiorstwa wydawniczego (art. 19 ust. 7 P.p. w pierwotnym brzmieniu). Zezwolenie nie było wymagane, jeżeli wydawca zamierzał wydawać wyłącznie jeden tytuł (art. 19 ust. 8 P.p. w pierwotnym brzmieniu).

Zgodnie $\mathrm{z}$ art. 20 ust. 1 P.p. (w pierwotnym brzmieniu) na wydawanie dziennika lub czasopisma wydawca obowiązany był uzyskać, niezależnie od zezwolenia, o którym mowa w art. 19 P.p., odrębne zezwolenie Głównego Urzędu Kontroli Publikacji i Widowisk. Wniosek o wydanie zezwolenia powinien był zawierać następujące dane:

- tytuł dziennika lub czasopisma oraz siedzibę i dokładny adres redakcji,

- dane osobowe redaktora naczelnego,

- określenie linii programowej dziennika lub czasopisma,

- określenie podstawowego zakresu tematycznego dziennika lub czasopisma,

- częstotliwość ukazywania się dziennika lub czasopisma, jego najwyższą objętość, format i najwyższy jednorazowy nakład oraz określenie zasięgu rozpowszechniania,

- wydawcę, jego siedzibę i dokładny adres,

- nazwę i adres zakładu poligraficznego, w którym dziennik lub czasopismo miałyby być wytwarzane, oraz określenie techniki ich wykonywania i źródło zaopatrzenia w papier (art. 20 ust. 2 pkt 1-7 P.p. w pierwotnym brzmieniu).

Dawny art. 21 ust. 1 P.p. określał przesłanki utraty ważności zezwolenia, w szczególności cofnięcia zezwolenia (bez dalszego precyzowania jego podstaw).

Obecnie obowiązujący art. 20 ust. 1 zd. 1 P.p. stanowi, że wydawanie dziennika lub czasopisma wymaga rejestracji w sądzie okręgowym właściwym miejscowo dla siedziby wydawcy. Wniosek o rejestrację powinien zawierać:

- tytuł dziennika lub czasopisma oraz siedzibę i dokładny adres redakcji,

- dane osobowe redaktora naczelnego,

- określenie wydawcy, jego siedzibę i dokładny adres,

- częstotliwość ukazywania się dziennika lub czasopisma (art. 20 ust. 2 pkt 1-4 P.p.). 
Wydawanie dziennika lub czasopisma można rozpocząć, jeżeli wniosku o rejestrację nie rozstrzygnięto w ciągu 30 dni od jego zgłoszenia (art. 20 ust. 4 P.p.). Dodatkowo należy zwrócić uwagę, że obecne postępowanie rejestracyjne jest rządzone przez kodeks postępowania cywilnego, a pierwotne wystąpienie o zezwolenie podlegało pod kodeks postępowania administracyjnego. Z okoliczności, że postępowanie rejestracyjne jest prowadzone obecnie przez sąd, można wywodzić, że celem było poddanie tego postępowania niezależnemu organowi. Jednak zarysowany $\mathrm{w}$ niniejszej publikacji problem wcale nie wiąże się $\mathrm{z}$ ewentualną stronniczością przy wydawaniu rozstrzygnięcia rejestracyjnego, lecz z przedmiotem rejestracji (wyznaczonym definicjami prasy - art. 7 ust. 2 pkt 1 P.p., dziennika - art. 7 ust. 2 pkt 2 P.p. i czasopisma - art. 7 ust. 2 pkt 3 P.p.), który został ukształtowany przed rewolucją internetowej. Obecnie zaś, pomimo że upłynęło niemało czasu od powstania mediów internetowych, wciąż rodzą się wątpliwości co do spełniania przez niektóre z nich definicji prasy, dziennika lub czasopisma.

Kontrowersyjna nie jest nawet działalność sądu rejestracyjnego, lecz sądu, który rozpoznaje sprawy na podstawie art. 45 P.p., stanowiącego, że kto wydaje dziennik lub czasopismo bez rejestracji albo zawieszone, podlega karze grzywny. Okoliczność, że obecnie jest to wykroczenie, a nie przestępstwo (jak to było przed 19 lipca 2013 roku), nie eliminuje tej kontrowersji, a jedynie zmniejsza dolegliwość. Można również zakładać, że istnienie takiej regulacji może skutkować „efektem mrożącym”, kiedy osoba nie będzie korzystała z wolności słowa z obawy, że z uwagi na formę jej działalność może być zakwalifikowana jako niezarejestrowane wydawanie dziennika lub czasopisma.

\section{Przesłanki odmowy rejestracji}

Organ rejestracyjny odmawia rejestracji dziennika lub czasopisma, jeżeli wniosek o rejestrację nie zawiera danych, o których mowa w art. 20 ust. 2 P.p., lub jeżeli jej udzielenie stanowiłoby naruszenie prawa do ochrony nazwy istniejącego już tytułu prasowego ${ }^{14}$ (art. 21 P.p.). Pierwsza $\mathrm{z}$ przesłanek jest $\mathrm{w}$ gruncie rzeczy oczywista i wiąże się z brakami formalnymi wniosku. Okoliczność, że braki w tym zakresie są podstawą odmowy, a nie podjęcia innej czynności procesowej kończącej sprawę negatywnym rozstrzygnięciem, jest konsekwencją przyjętej konstrukcji. Natomiast druga z przesłanek jest o tyle istotna, że wskazuje się ją jako zasadnicze uzasadnienie istnienia obowiązku rejestracji dzienników i czasopism ${ }^{15}$. Dbałość o ochronę nazwy istniejącego tytułu prasowego ma być głównym celem postępowania rejestracyjnego. Chodzi o ochronę głównie

14 Odnośnie do pojęcia tytułu prasowego zob. między innymi G. Tylec, Obowiazek rejestracji tytutów prasowych, [w:] idem, Ochrona tytutu utworu w prawie polskim, Warszawa 2006.

15 Zob. między innymi W. Lis, Procedura rejestracji tytutu prasowego. Problemy regulacyjne, ,Rocznik Bibliologiczno-Prasoznawczy” 16, 2013, nr 5, s. 144-147. 
o charakterze majątkowym. Jest ona jednak realizowana już na gruncie innych regulacji (prawo własności intelektualnej i prawo o zwalczaniu nieuczciwej konkurencji), zatem takie dodatkowe umocnienie tej ochrony w prawie prasowym jest nieadekwatne do potrzeb.

Ochrona tytułu prasowego przez prawo prasowe jest również o tyle iluzoryczna, że nie jest trwała, ponieważ w myśl art. 23 P.p. rejestracja dziennika lub czasopisma traci ważność $\mathrm{w}$ razie niewydania dziennika lub czasopisma przez okres roku od dnia nabycia uprawnień do ich wydawania na czas nieoznaczony lub przerwy w ich wydawaniu przez okres roku, jeżeli redakcja nie wystąpiła o zachowanie rejestracji.

Choć można zgodzić się z twierdzeniem, że zarejestrowanie prasy nie jest procedurą skomplikowaną, to jednak, technicznie rzecz ujmując, rozpoczęcie działalności prasowej też jest, z racji postępu technologicznego, równie nieskomplikowanym działaniem. Może się nawet zdarzyć, że faktyczne rozpoczęcie wydawania dziennika lub czasopisma nie będzie nawet objęte zamiarem. Teza o nieskomplikowaniu procedury rejestracyjnej jest zatem o tyle nieprawdziwa, że obecnie niekiedy na tle samego faktycznego rozpoczęcie wydawania prasy procedura ta jest wysoce skomplikowana. Może się okazać, że w niektórych przypadkach opłata za wniosek o rejestrację dziennika lub czasopisma będzie większym obciążeniem finansowym niż rozpoczęcie wydawania e-dziennika lub e-czasopisma.

\section{Wnioski}

W świetle przedstawionej uproszczonej ewolucji regulacji dotyczących rozpoczęcia wydawania prasy wyróżnia się regulacja wymagająca zezwolenia na wydawanie dziennika i czasopisma. Niewątpliwie jest to regulacja cechująca państwo autorytarne lub totalitarne. Okoliczność, że w wymiarze legislacyjnym obecny wymóg rejestracji dzienników i czasopism jest „następcą legislacyjnym” tej regulacji, jak się wydaje, nie ma jedynie wymiaru redakcyjnego. Może się rodzić pytanie, czy demokratyczną alternatywą dla uzyskania zezwolenia na wydawanie prasy jest konieczność jej zarejestrowania. Obowiązek rejestracji byłby akceptowalny, gdyby przemawiały za nim określone wartości, w tym wzgląd na interesy innych osób i podmiotów. Jednak obecnie takie interesy są zabezpieczone przez inne regulacje. Wreszcie trzeba uwzględnić, że wskutek upowszechnienia internetu i sprzętu komputerowego zarejestrowanie tytułu prasowego jest bardziej skomplikowane niż rozpoczęcie prostej działalności prasowej.

Ewentualne zmiany prawne nie powinny jednak polegać na doprecyzowaniu brzmienia regulacji, ponieważ można przypuszczać, że w dalszej perspektywie nie rozwiąże to problemów, a może jedynie przyczynić się do powstania kolejnych wątpliwości. Zmiany powinny polegać przede wszystkim na deregulacji. 
W gruncie rzeczy dla rozwiania wszelkich wątpliwości - nie tylko wątpliwości o charakterze konstytucyjnym, lecz także praktycznych mankamentów stosowania regulacji prasowych - wystarczyłoby, aby rejestracja dzienników lub czasopism nie była obowiązkowa. Inaczej ujmując: przedstawione rozwiązanie oznaczałoby, że brak rejestracji nie wiązałby się z żadną sankcją czy, dokładnie mówiąc, z żadną negatywną konsekwencją ${ }^{16}$. Legislacyjnie polegałoby to na uchyleniu przepisów czyniących wykroczenie $\mathrm{z}$ braku rejestracji. Nie oznacza to jednak, że zarejestrowanie danego tytułu dziennika lub czasopisma nie wiązałoby się z określonymi przywilejami.

Oddzielić należy od siebie dwie kwestie - samą rejestrację i sankcję za brak rejestracji. Brak rejestracji wcale nie musi się wiązać z negatywnymi konsekwencjami. Hipotetycznie możliwy byłby taki kształt regulacji, że rejestracja jest konieczna, ale tylko na potrzebę uprzywilejowania osoby lub podmiotu wnioskujących o rejestrację. W gruncie rzeczy takie przywileje są wprost określone i ogólnie można je nazwać uprawnieniami dziennikarskimi.

Nie można również wykluczyć propozycji legislacyjnej zakładającej, że tylko zarejestrowane dzienniki lub czasopisma byłyby prasą $\mathrm{w}$ rozumieniu prawa prasowego. Legislacyjnym wyrazem takiego rozwiązania byłoby dodanie do definicji dziennika lub czasopisma jako elementu koniecznego właśnie zarejestrowania dziennika lub czasopisma. W efekcie to wnioskodawca decydowałby, czy chce prowadzić dziennik lub czasopismo w rozumieniu prawa prasowego (koniecznym byłoby przy tym spełnienie innych przesłanek dziennika i czasopisma, a w szczególności definicji prasy). Należy zauważyć, że przy takich założeniach wciąż byłaby to prasa, ale nie byłyby to dziennik lub czasopismo.

\section{Bibliografia}

Balcarczyk J., Prasa internetowa - rejestracja?, „Prawo Mediów Elektronicznych” 2010, nr 1.

Banaszak B., Komentarz do art. 54, [w:] idem, Konstytucja Rzeczypospolitej Polskiej. Komentarz, Warszawa 2012, Legalis, nb 12.

Barta J., Markiewicz R., Postęp techniczny w mediach, [w:] Prawo mediów, red. J. Barta, R. Markiewicz, A. Matlak, Warszawa 2005.

Brzozowska-Pasieka M., Komentarz do art. 20, [w:] Prawo prasowe. Komentarz praktyczny, red. M. Olszyński, J. Pasieka, M. Brzozowska-Pasieka, Warszawa 2013.

Czarny-Drożdżejko E., Glosa do postanowienia SN z dnia 26 lipca 2007 r., IV KK 174/07, „Przegląd Prawa Publicznego" 2008, nr 9.

Czarny-Drożdżejko E., Obowiązkowa rejestracja dzienników i czasopism na gruncie ustawy — Prawo prasowe, „Przegląd Sądowy” 2013, nr 10.

Ferenc-Szydełko E., Komentarz do art. 20, [w:] Prawo prasowe. Komentarz, Warszawa 2013.

16 Por. E. Czarny-Drożdżejko, Glosa do postanowienia SN z dnia 26 lipca 2007 r., IV KK 174/07, „Przegląd Prawa Publicznego” 2008, nr 9, s. 84; J. Balcarczyk, Prasa internetowa - rejestracja?, „Prawo Mediów Elektronicznych” 2010, nr 1, s. 13-16. 
Habielski R., Ewolucja prawa prasowego w Drugiej Rzeczypospolitej. Zakres i recepcja, „Studia Medioznawcze" 2013, $\mathrm{nr} 4$.

Klafkowska-Waśniowska K., Elektroniczne wersje gazet $i$ czasopism a audiowizualne ustugi medialne w prawie Unii Europejskiej i prawie polskim. Glosa do wyroku TS z dnia 21 października 2015 r., C-347/14, „Europejski Przegląd Sądowy” 2016, nr 8.

Lis W., Procedura rejestracji tytulu prasowego. Problemy regulacyjne, „Rocznik Bibliologiczno-Prasoznawczy" 16, 2013, nr 5.

Machaj Ł., Glosa do wyroku TK z dnia 9 listopada 2010 r., K 13/07, „Przegląd Sejmowy” 2011, nr 3.

Malinowski S.J., Status prawny Internetu w świetle Konstytucji RP i obowiazujacego prawodawstwa polskiego, „Prawo Mediów Elektronicznych” 2020, nr 1.

Nowińska E., Wolność wyrażania poglądów a cenzura prewencyjna. Próba interpretacji Konstytucji, [w:] eadem, Wolność wypowiedzi prasowej, Warszawa 2007.

Paczoska K., Komentarz do art. 20, [w:] Prawo prasowe. Komentarz, red. B. Kosmus, G. Kuczyński, Warszawa 2018, Legalis, nb 4.

Sadomski J., Komentarz do art. 54, [w:] Konstytucja RP. Komentarz, red. M. Safjan, L. Bosek, Warszawa 2016, Legalis, nb 34.

Sieńczyło-Chlabicz J., Zawadzka Z., Nowikowska M., Historia prawa prasowego w Polsce. Podstawowe pojęcia z zakresu prawa mediów, [w:] Prawo mediów, red. J. Sieńczyło-Chlabicz, Warszawa 2015.

Sokolewicz W., Wolność prasy i jej konstytucyjne ograniczenia, „Państwo i Prawo” 2008, nr 6.

Stępniak K., Prawo do Internetu jako środka zapewniajacego partycypację w państwie demokratycznym, „Studia Prawnicze i Administracyjne” 2017, nr 3.

Taczkowska-Olszewska J., Racjonalizacja wolności prasy — od modelu absolutnego do warunkowego. Europejski i krajowy kontekst wyktadni prawa, „Przegląd Sejmowy” 2018, nr 1.

Tylec G., Obowiązek rejestracji tytułów prasowych, [w:] idem, Ochrona tytulu utworu w prawie polskim, Warszawa 2006.

Zieliński M., Dostęp do Internetu jako prawo człowieka? W sprawie potrzeby nowej wolności w Konstytucji Rzeczypospolitej Polskiej, „Przegląd Sejmowy” 2013, nr 4. 